\title{
ショアかたさ基準片についで
}

関谷 三 郎**

\section{On Shore Hardness Standard Blocks}

by

\author{
Saburo SekiYa \\ (Faculty of Engineering University of Tokyo, Tokyo)
}

\begin{abstract}
ショアかたさ試験機は，取り扱いが簡便で，測定値が容易に得られるため，現在工業界で，素材の材質チ ェックはもちろんのとと, 大寸法, 大重量の工業部品の品質管理と品質保証に盛んに利用されている。しか し，ショアかたさ測定值が工業的に比較可能な数值として，取り报えるのは，共析鋼製ショアかたさ基準片 を用いて，試験機の管理，調整を行なって，はじめて信頼性の高い数值が得られるのである。しかし基準片 亿記入されている基準值は，試験機の構造上，および耐用度の点からショアかたさ試験機を用いて求められ たものでなく，ビッカースかたさのような静的な測定結果より，換算によって求められたものである。した がって，静的なかたさとショアのような動的なかたさの関係を調べるととは，ショアかたさ測定值の信頼性 向上の上から必要なととである。

本研究では，焼入れ，焼もどしなどの熱処理によって製作された基準片を試料とし，その中央部を切断 し, 切断前後の試料表面の精密なかたさ測定の結果から, 巨視的な残留応力の一部解放された場合, 静的, 動的なかたさ試験において，その試験方法の相違により，かたさ測定值がどのように影響を受けるかを調 べまた，共析鋼製試料の表面および内部の顕微鏡組織とかたさ分布，かたさのばらつきの関係を調へ，あ わせて焼入れの深度などを検討した。
\end{abstract}

\section{1 緒 言}

ショアかたさ基準片は，かたさ基準の保持ならびに 測定值の信頼性向上を図るうえに，必要久くべからざ るものである. 現在ショアかたさ測定值が工業的に比 較可能な数值として, 広く一般に利用されているのは, このかたさ基準片を用いて，試験機の管理，調整が行 なわれるからである。ショアかたさ基準片には通常基 準片の表面にかたさ基準值が記入されている。しかし， この数值は，直接ショアかたさ試験機を用いて決定さ れたものではない. ショアかたさ試験機は，その機 能，構造および耐用度などの制約から，標準的な試験 機を製作することが困難なため，静的なビッカースか たさの測定值より，JIS の規定に基づいて換算し，動 的なショアかたさの基準值としているものである.

ショアかたさ基準片は，共析鋼製鋼板を機械加工し， 焼入れ, サブゼロ処理, 焼もどしなどの熱処理を行な って製作されるので，表面部または内部に巨視的な応 力が残留して，かたさの測定値に影響を与えるととが 考えられる。しかし一般に行なわれているかたさ試験 法, すなわち, ブリネルかたさ試験法, ・ビッカースか

* 原稿受理 昭和41年10月 12 日

** 正会員 東京大学工学部 果京都文京区本郷 7
たさ試験法, ロックウェルかたさ試験法, ショアかた さ試験法などは, 定義, 試験方法, 試験条件などそれ ぞれ異るっている。したがって残留応力のある試料の かたさ測定を行なう場合, 測定值への影響の程度が異 なるものと考えられる。そこで一例として，共析鋼製 の高硬度ショアかたさ基準片を試料とし，その試料中 央部の切断を行なって, 巨視的な残留応力の一部を解 放し, 切断前後のビッカースかたさ，ロックウェルか たさ, ショアかたさの精密な測定を行なって, 応力除 去とかたさ測定值の関係を検討した。 その結果, ビッ カースかたさでは試料の応力の一部か除去されても, 測定值にはあまり影響がみられず，ロックウェルかた さ, ショアかたさでは応力の一部除去により, 測定值 が若干の影響を受けるとの結論を得た。

また，乙の際試料断面のビッカースかたさの分布を 求め, 煤入れの深度, 中心部の汃たさ，および表面よ り中心部に至る顕微鏡組織の変化との関係を調べた。

\section{2 試料}

試料には共析鋼製ショアかたさ基準片を用いた。乙 の試料の材質はJIS 炭素鋼工具鋼 5 種で，圧延率を 25 以上に取り, 厚さ $20=1 \mathrm{~mm}$, 幅約 $75 \mathrm{~mm}$ の鋼板を素 材とした．結晶組織の調整および内部応力除去のため, 
$740^{\circ} \mathrm{C} \rightleftarrows 728^{\circ} \mathrm{C} 6$ 時間保持後, $350^{\circ} \mathrm{C}$ まで約 5 時間徐冷 して, 焼なましを行なった. 機械加工は直径約 $64 \mathrm{~mm}$ に 仕上げ，上下面を同量切削して，厚さ約 $16 \mathrm{~mm}$ 亿仕上 げた。焼入れは図1に示すように行ない，試料のかた

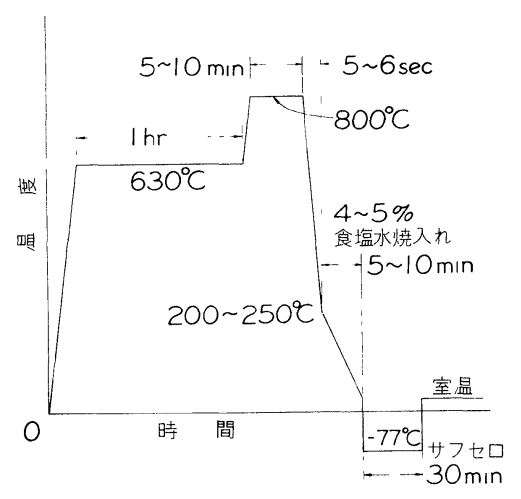

図 1 試料の烧入温度と時間

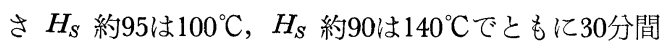
保った後, 空冷して焼もごしを行なった。

この種のかたさの試料は，焼もどし温度が低いため， 試料の表裹面および内部に巨視的な応力が残留してあ ると考えられる。

\section{3 試料の切断およびかたさの測定方法}

前項の手順で製作された，共析鋼製かたさ基準片， $H_{S}$ 約 95 を 5 個, $H_{S}$ 約 90 を 5 個, 計10個を試料とし た.

切断は熱的な影響によって，試料が焼なまされない ように，自家製の RGL 回路放電加工機を用い，図 2 に示すように，試料の中央部を切断した.

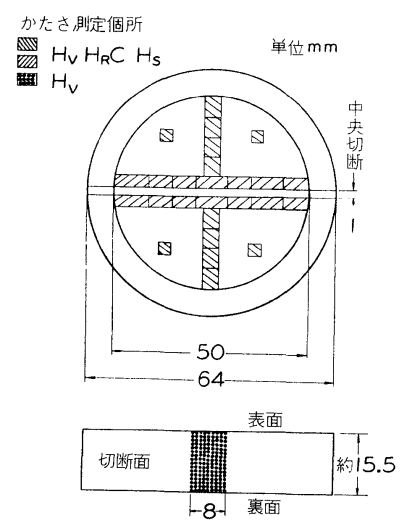

図 2 武料の切断とかたさ測定個所

かたさの測定は，切断前に前もって，切断予定線と 平行に両側に10点(切断後の端面より約 $2 \mathrm{~mm} の$ 位置), 切断予定線と直角方向に約 $5 \mathrm{~mm}$ 間隔で 8 点, および 周辺部 4 点, 総計 22 点のビッカースかたさ $(50 \mathrm{~kg}$ 荷重 使用)，ロックウェルかたさ（Gスケール使用)，ショ アかたさ (D型試験機使用)の測定を行ない，切断後は
前の測定位置のきわめて近傍について，同様な測定を 行なった. なお，測定開始前と終了後に，別にチェッ ク用基準片 3 個を用意して, 試験機および測定者によ るかたさ測定值に狂いの生じていないてとを確かめた。 また, D型ショアかたさ試験機のフレームは, 全重量27 $\mathrm{kg}$ 特製機わく(一体アンビルでプラグの打込みなし) を使用したので機わくによるトラブルは避けられたも のと思う.

試料断面のかたさ分布測定は，かたさ值に影響がな いように切断面を充分注意しながら泠却し，鏡面仕上 した。 ビッカースかたさの測定は, 微小硬度計 $(1 \mathrm{~kg}$ 荷重使用)を用いて，図 2 亿示すように切断面中央部 を試料深さ方向に約 $1 \mathrm{~mm}$ 間隔で 5 点ずつ測定し，表 面部より裏面までのかたさ分布を求めた。

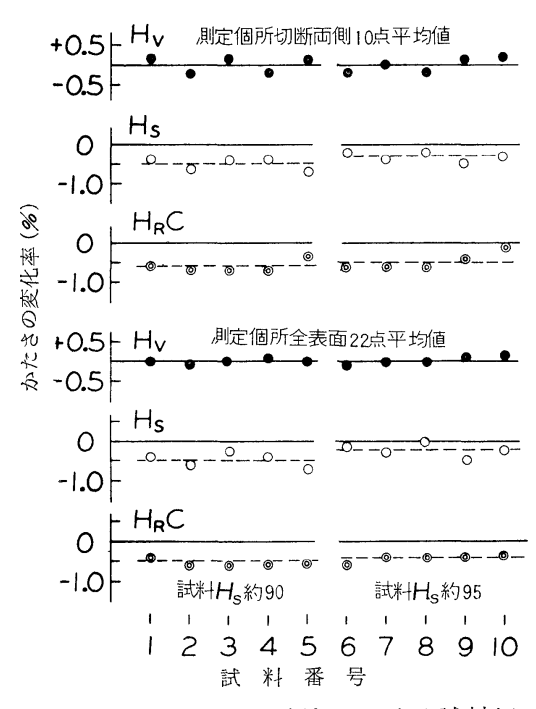

図3各種功たさ試験法における試料切 断前之切断後のかたさの変化率

\section{4 測 定 結 果}

図 3 は， $H_{S}$ 約 900 試料 5 個（No. 1，2，3，4，5）, $H_{S}$ 約 95 の試料 5 個 (No. $6,7,8,9,10$ ) 亿ついて切 断前後の測定結果 (切断両側10点および全表面22点)か ら, 変化率 $(\%)$ を次のように定義して図示した。

$$
\text { 変化率 }(\%)=\left\{\left(\bar{X}_{a}-\bar{X}_{b}\right) / \bar{X}_{a}\right] \times 100
$$

ただし， $\bar{X}_{a}:$ 切断後のかたさの平均值

$\bar{X}_{b}:$ 切断前のかたさの平均值

図 4 は， $H_{S}$ 約 90 の試料 5 個および $H_{S}$ 約95の試料 5 個の切断面の鏡面仕上を行ない，端面より中心部へ と厚さ方向へビッカースかたさ（1 kg 荷重使用） 5 点 測定し，その平均值と表面からの距離の関係を図示し たものである。 5 個の試料で表面近くのかたさ值はあ まり相違がなくとも，心部のかたさ值は相当の相違が あるととがわかる。

困 5 は，上記 2 種類の試料の表面のかたさ值を 100 


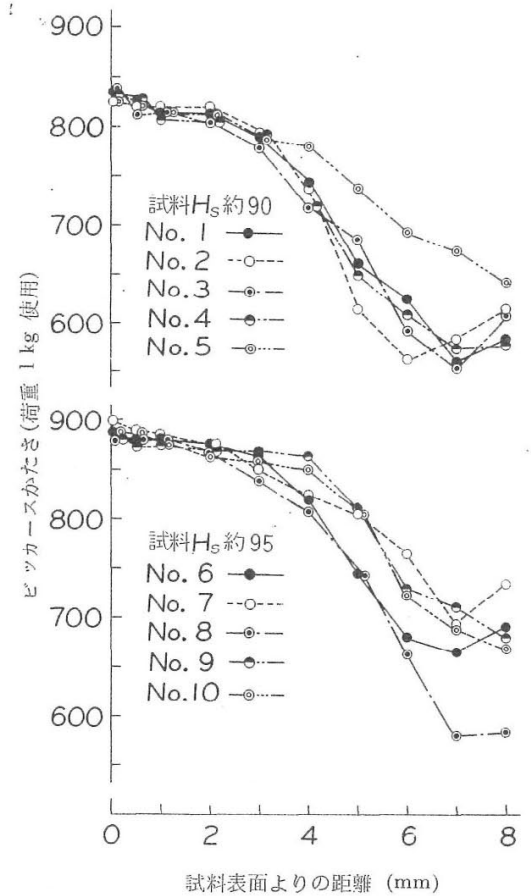

図4 試料切断面のビッカースかたさの分死

\%とした場合，表面より内部抢よび裏面へとかたさ优 の変化を示してある。乙れによると，試料の心部の かたさ值情表面のかたさ値の約 $70 \%$ 程度であるととが わかる。また同一ロットで製作さ扎て試料で吕，内部 のかたさ值には相当の差違のあることがわかる。

図6 钓断面について, 表面よりの距離とかたさ のばらつきの ( 5 点測定の標準偏差) の関係在示す。 内部はかたさ招らが非常に大きいとと走示している。

図7は。試料 $H_{s} 95$ No. 6 の表面㧍上び表面より厚 み方向 $2.5,6,7.5 \mathrm{~mm}$ の位置の切断面の顕德鏡組織定 示す。試料表面はマルテンサイト組縕であるが，漸次 内部に至るにしたがって，トルースタイ組織か現わ扎

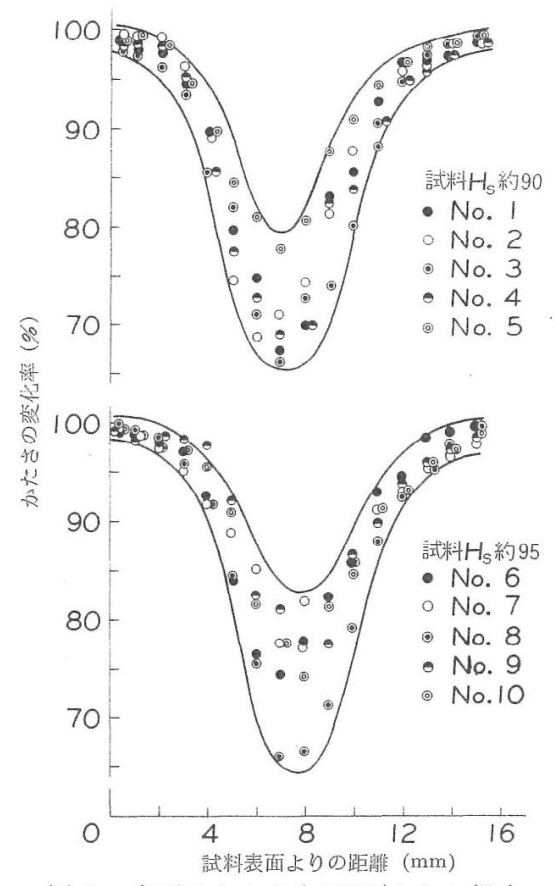

図 5 表面の汃たさを $100 \%$ 上した場合， 試料断面の汃たさの变化率

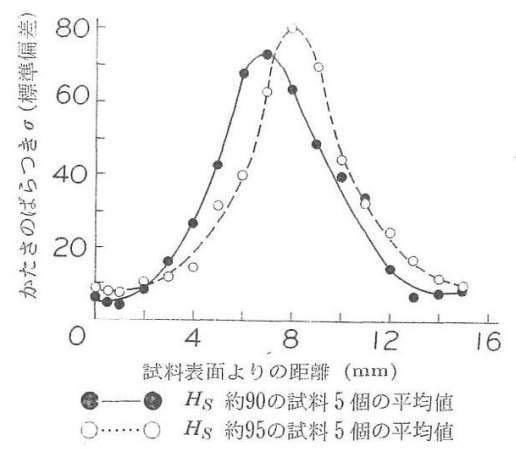

図 6 试料断面のかたさのばらつき ( $H_{Y}$ 荷重 $1 \mathrm{~kg}$ 使明 5 点测定)

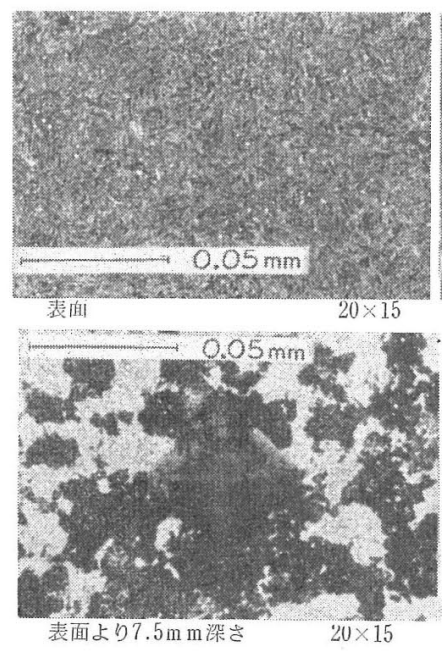

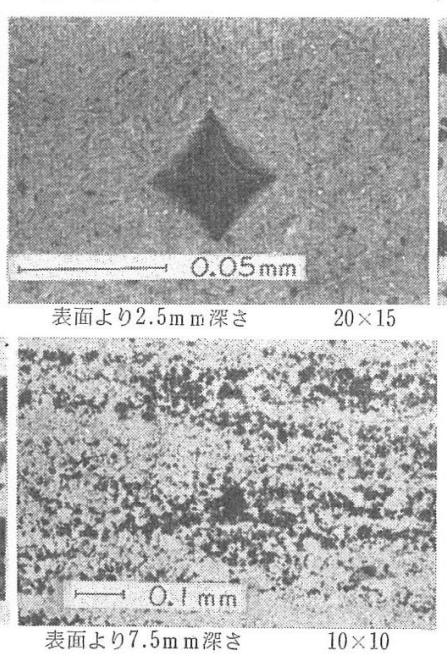

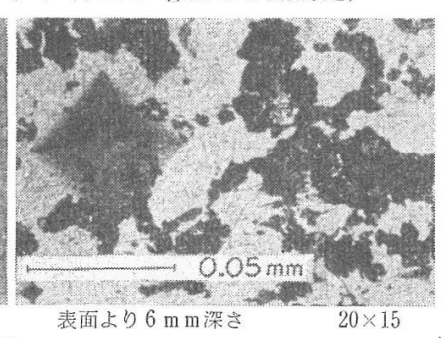

四 $7 H_{S}$ 約950武料( No.6) 0内部組織 $(\times 1 / 2)$ 
て，中央部 (表面より $7.5 \mathrm{~mm}$ の位置) になると，乙れ らの混合組織になっている。したがって表面より内部 に至るに従って，かたさ傾も低下し，またばらつき $\sigma$ の值も大きくなってくる。

\section{5 考察}

焼入れサブゼロ処理，焼もどしなどの熱処理によっ て製作される共析鋼製かたさ基準片，特江高硬度基準 片を試料として，試料中央部の切断を行ない，その前 後のかたさの精密な測定結果から次の推論を行なった。 (1) 一般に応力とかたさの関係は, 試料に圧縮力が 加わるとかたさ值は高めに，引張力が加わるとかたさ 值は低めの值を示す。したがって共析鋼製かたさ基準 片の表面に残留するといわれる応力は压縮である。

（2）圧縮力が試料表面に存在すると，圧子の圧入に 対する抵抗が影響され，除荷後のくぼみの変形にも影 響が加わる. 図 3 亿示すように, ショアかたさおよび ロックウェル $G$ かたさの测定結果は, 試料切断前と切 断後で変化する．つまり压縮応力の一部が除去される とかたさ值は低下する。

（3）ただし，図 3 に示すビッカースかたさの結果で は前述の結論を見いだすととができなかった。てれは ビッカースかたさの場合, 応力の一部解放に基づく対 角線長の変化の少ないとととともに，測定精度（本実 験ではくぼみ対角線の長さ $\pm 0.5 \mu の$ 変化がビッカース かたさ 2.5 に相当する)や試料自体のかたさのばらつ きを考えると, 量的に小さい応力変化に対して，かた さの変化が現われなかったものと思われる.

（4）ショアかたさは，ハンマが試料に圧入された後, くぼみの持つ弾性エネルギによって, かたさ值が指示 されるので, 試料表面の圧縮応力のいかんは, 弾性工 ネルギに影響を与えることが考えられる。実験結果も， $0.2 \sim 0.5 \%$ の変化率を示している.

（5）ロックウェル $C$ かたさは, 試験荷重を除いた後, 残留くぼみの深さで測定值が得られるので, ショアか
たさ同様，その測定值は応力の大小によって影響を受 ける. 実験結果も約 $0.5 \%$ 率化率を示している。

（6）共析鋼製かたさ基準片の焼入れの深度は断面か たさ分布の図 4,5 に示すように，表面よりほぼ 2 $\mathrm{mm}$ 程度と考光てよい. しかし，心部のかたさは同一 ロット，同一条件で製作された試料でも，相当の差異 があり，またかたさのばらつきも図 6 亿示すように大 ののきいてとがわかる。

\section{6 結}

\section{言}

共析鋼製かたさ基準片はショアかたさ基準片ばかり でなく，ロックウェルかたさ基準片，ビッカースかた さ基準片にも使用されている。 その表面に残留する生 縮応力は，量的には小さい量と推定されるが，かたさ 試験法によってその測定值への影響の程度が異なる。 つまり応力に刘する敏感の度合いは, ロックウェルか たさが大きく,次いでショアかたさであり,ビッカース かたさは小さいといえる。したがってビッカースかた さより換算してショアかたさを求める場合や，各種か たさ基準片を用いて，それぞれのかたさの長期管理を 行なう場合, くぼみ数の増加, 経年変化その他による 基準片表面の巨視的な応力変化に注意する必要がある.

終わりに本研究について, 直接で指導をいただいた 東京大学 吉沢教授，ならびに試料の製作にご協力い ただきました(森)山本科学工具研究社 山本普氏に深く 感謝いたします。

(昭和 40 年 5 月 18 日，41年 5 月 18 日 日本材料学会第 $14 ， 15$ 期総会講 崔会にて講倣）

\section{参 考 文 献}

1）ショアカタサ基準片, JIS B 7731 (1964).

2）吉沢武男, 関谷三郎, 材料, 13, 129 (1964).

3）大和久重雄, 宮下春好, 力夕サ研究会資料, 3236 (1957).

4）平修二, 吉阔靖夫, 材料試験, 11, 386 (1962).

5）青山咸恒，並川宏彦，材料， 13, 999 (1964). 